\title{
Compliance a kvalita života u pacientů s antikoagulační léčbou: první výsledky pilotní studie
}

\section{Compliance and quality of life in patients with anti-coagulation treatment: first results of the pilot study}

\author{
Anna Zatloukalová ${ }^{1,2,3}$, Miroslav Homza ${ }^{4}$, Martina Kovalová \\ ${ }^{1}$ Ústav epidemiologie a ochrany veřejného zdraví, Lékařská fakulta, Ostravská univerzita, \\ Ostrava, Česká republika \\ ${ }^{2}$ Ústav zdravotnického managementu, Fakulta zdravotnických věd, Univerzita Palackého v Olomouci, \\ Olomouc, Česká republika \\ ${ }^{3}$ Centrum vědy a výzkumu, Fakulta zdravotnických věd, Univerzita Palackého v Olomouci, \\ Olomouc, Česká republika \\ ${ }^{4}$ Katedra interních oborů, Lékařská fakulta, Ostravská univerzita, \\ Ostrava, Česká republika
}

\section{ABSTRAKT}

Východiska: Nová př́má perorální antikoagulancia (DOAC) představují novou komfortní volbu v antikoagulační terapii. Studie se zaměřovala na kvalitu života a compliance u těchto pacientů.

Cíl: Cílem bylo zjistit kvalitu života a compliance pacientů užívající DOAC a Warfarin a jejich rizikové faktory. Metody: Studie využívala dotazníkovou metodu zjištění kvality života a compliance (SF 12 a rošírený dotazník MMAS-8). Výběrové kritérium bylo uživání Warfarinu, Pradaxy, Qarelta nebo Eliquisu.

Výsledky: Ve výsledcích kvality života a compliance u DOAC a Warfarinu nebyl zjištěn statisticky významný rozdíl.

Závěry: Studie zjistila mnohé rizikové faktory u pacientů s antikoagulační léčbou. Je třeba pacienty edukovat o léčbě a možnosti prevence aby dosáhli maximálního potenciálu zdraví, tedy optimální kvality života a vysoké compliance u antikoagulační léčby.

\section{ABSTRACT}

Background: The new direct oral anticoagulant (DOAC) creates a new comfortable choice in anticoagulant therapy. A study focused on the quality of life and compliance in these patients.

Objective: The aim was to determine the quality of life and compliance of patients taking DOAC and Warfarin and their risk factors.

Medhods: The study used a questionnaire method to determine quality of life and compliance (SF 12 and the extended MMAS-8 questionnaire). The selection criterion was the use of Warfarin, Pradaxa, Qarelt or Eliquis.

Results: There was no statistically significant difference in DOAC and Warfarin quality of life and compliance outcomes.

Conclusions: The study identified many risk factors in patients on anticoagulant therapy. Patients should be educated about treatment and prevention to achieve maximum health potential, ie optimal quality of life and high compliance with anticoagulant therapy.

KLÍČOVÁ SLOVA

antikoagulancia, compliance, kvalita života, rizikový faktor

KEY WORDS

anticoagulants, compliance, quality of live, risk factor 


\section{ÚVOD}

Antikoagulační léčba učinila $\mathrm{v}$ posledních letech velký krok kupředu. $\mathrm{V}$ minulosti najčastěji užívané perorální antikoagulancium warfarin v poslední dekádě postupně nahrazují takzvaná nová přímá perorální antikoagulancia - DOAC (z anglického Direct Oral AntiCoagulants). Konkrétně se jedná o prrímé inhibitory trombinu (takzvané gatrany - dabigatran) a prímé inhibitory faktoru Xa (takzvané xabany - rivaroxaban, apixaban, edoxaban). Oproti warfarinu mají četné výhody a to nejen minimálně stejný či lepší bezpečnostní profil, ale i odpadnutí nutnosti monitorace, což se jeví jako velká výhoda zejména pro samotné paciety. Najčastější indikace DOAC je fibrilace síní (FS). Jako u každé léčby je třeba zajistit u pacienta porozumění medikace a uživání antikoagulancií, tedy zajistit co nejvyšší compliance (v překladu dodržení, vyhovění) a adherenci (přilnutí, dodržování) pacienta $\mathrm{k}$ léčbě. Pouze pak může nabýt předepsaná medikace maximálního potenciálu a reálně léčit daný problém. Současně je dostatečná compliance podmínkou pro dosažení maximálního zdravotního potenciálu jedince a tím tedy dosáhnout nejvyšší možnou kvalitu života. Užívání DOAC oproti antagonistům vitaminu $\mathrm{K}$ (VKA) je méně náročné, což zvyšuje kvalitu života pacientů. Velmi často se u pojmu compliance objevuje i pojem adherence. Jsou to termíny často velmi provázané a nelze je často jednoduše oddělit.

Antikoagulační účinek NOAC rychle mizí 12-24 hodin po posledním užití. Důsledná adherence k předepsanému užívání medikace je proto naprosto nezbytná. Nedávno získané údaje $\mathrm{z}$ praxe prokázaly sníženou incidenci ischemických CMP i mortalitu pacientů léčených dabigatranem oproti warfarinu, což ukazuje na odpovídající adherenci. Pacienti s vyšší morbiditou vykazovali lepší adherenci $k$ dabigatranu. Existují i důkazy o významně nižších procentech přerušení léčby u pacientů uživajících NOAC ve srovnání s pacienty užívajícími VKA (vitamin $\mathrm{K}$ antagonist antagonisté vitaminu $\mathrm{K}$ ).

$\mathrm{V}$ doporučených postupech se uvádí $\mathrm{k}$ tématu adherence hned několik praktických poznámek (1).

1. Maximálně důležité je poučení pacienta o významu důsledné adherence. Pro tento účel byla vypracována řada vzájemně se doplňujících postupů: letáčky a pokyny při zahájení léčby, kartička o antikoagulaci pro pacienta, opakovaná edukace vždy při každém vystavování nového receptu. $\mathrm{Na}$ webových stránkách nabízí podporu pacientovi několik organizací včetně EHRA (European Heart Rhythm Association).

2. Edukovat je nutno i rodinné př́islušníky, aby si uvědomovali důležitost adherence.
3. Pro pacienty užívající DOAC musí být předem specifikovaný harmonogram kontrol, který budou znát a vzájemně sdílet praktičtí lékaři, lékárníci, zdravotní sestry, antikoagulační ambulance i další profesionální pracovníci poskytující péči. O každém opatření je nutno informovat všechny ostatní výše uvedené osoby, např̀. vyplněním řádky v kartičce o antikoagulaci s podáváním NOAC.

4. V některých zemích existuje pečlivě propracovaná databáze lékáren, díky níž lze sledovat počty předpisů vystavených na NOAC.

5. Ve snaze o zvýšení adherence se hodnotí řada různých pomůcek: velikost blistrů, krabičky s léky (klasické nebo s elektronickým ověřováním užívání); aplikace pro chytré telefony s upomínkami a/nebo SMS zprávami upozorňujícími pacienta na nutnost užití léku.

6. U pacientů $s$ kardiovaskulárním onemocněním i u pacientů s FS je dávkovací režim podávání jedenkrát denně spojen s vyšší adherencí než dávkovací režim podávání dvakrát denně.

7. Někteří pacienti mohou výslovně dávat přednost monitorování INR před nemonitorováním nebo léčbě s podáváním NOAC před uživáním VKA.

8. U pacientů s NOAC s podezřením na jejich nízkou adherenci přes řádné poučení a další nástroje je vhodné zvážit jejich převedení na VKA (1).

Co se týče kvality života u pacientů $s$ antikoagulační léčbou litevská studie z roku 2017 potvrdila, že užívání DOAC koreluje s nejvyššími hodnotami skóre kvality života v souvislosti se zdravím; byl nalezen statisticky významný rozdíl oproti osobám užívajícím warfarin $\mathrm{v}$ dimenzi fyzického fungování (warfarin 95,85; NOAC 124,57; $\mathrm{p}=0,012)$ i sociálního fungování (warfarin 95,16; NOAC 119,08; $\mathrm{p}=0,026$ ) (2).

Ve francouzské observační popisné epidemiologické studii publikované $\mathrm{v}$ roce 2018 byla posuzována kvalita života, spokojenost $s$ léčbou a adherence $\mathrm{k}$ léčbě. Jednalo se o pacienty s fibrilací síní užívající antikoagulační léčbu alespoň 3 měsíce. Následně byli rozděleni do 4 skupin: primární VKA (P-VKA), přechod $\mathrm{z}$ VKA na DOAC (S-DOAC), primární DOAC (P-DOAC) a přechod z DOAC na VKA (S-VKA). Statisticky byly porovnány pouze první trři skupiny kvưli malé velikosti skupiny S-VKA. Kvalita života a spokojenost byly dobré ve všech třech skupinách, bez výrazného rozdílu $\mathrm{v}$ kvalitě života, ale $\mathrm{s}$ výrazně větší spokojenosti s ohledem na dimenze „pohodlí a „spokojenosti“ pro DOAC (skupiny S-DOAC a P-DOAC versus $\mathrm{P}$ - Skupina VKA; $\mathrm{p}<0,001$ pro oba rozměry). Dodržování se mezi skupinami významně nelišilo. Zkušenosti pacientů s perorální antikoagulační terapií rízenou ambulantně byly dobré, kvalita života byla 
u DOAC a VKA srovnatelná a dokonce bylo zjištěno signifikantně větší uspokojení u DOAC a to bez dopadu na adherenci (3).

Tématu compliance a kvalitě života se věnovala studie s názvem: „Životní styl, kvalita života a compliance pacientů užívajících antikoagulancia-pilotní studie“.

\section{CIIL PRÁCE}

Hlavním cílem projektu bylo zjistit informace o pacientech užívající antikoagulancia a to v oblasti životního stylu, kvality života a compliance.

\section{METODIKA}

Informace byly získány pomocí dotazníkového šetření na pilotním vzorku pacientů kardiologické ambulance Benedor v Ostravě. Základním vstupním kritériem byl podpis informovaného souhlasu a užívání warfarinu, dabigatranu, rivaroxabanu, apixabanu nebo edoxabanu. Dotazníky byly vyplňovány s pomocí přítomného zdravotníka. Dotazník obsahoval 5 částí viz obrázek 1.

Dotazník v části A - C je tvořen výběrem/modifikací otázek standardizovaných dotazníků použitých ve významných studiích jako je např́klad EHIS (European Health Interview Survey) Evropské výběrové šetření o zdraví, ELSA (English Longitudinal Study of Ageing) či HELEN (Health, Life Style and Environment) - Zdravotní stav obyvatelstva v rámci Systému monitorování MZ ČR. Podkladem pro vytvoření části D a E byl dotazník kvality života SF-12 (zkrá- cená verze SF-36) a modifikace Moriskiho dotazníku (MMAS-8) s doplněním vlastních otázek.

Data byla získána $\mathrm{v}$ průběhu jara 2019 až začátkem roku 2020. Od té doby se výzkum vzhledem k nepříznivé epidemiologické situaci pozastavil.

\section{VÝSLEDKY}

\section{Základní charakteristika souboru}

Pilotní studie se zúčastnilo prozatím 39 osob, z toho 23 mužů (59 \%) a 16 žen (41\%). Průměrný věk v souboru bez rozlišení pohlaví byl 73,1 let (SD 7,99; min. 49; max. 84). Při rozlišení pohlaví byl průměrný věk mužů 72,9 let a žen 73,4 let. Většina respondentů byla ve věku nad 60 let, a to konkrétně $64,4 \%$ ve věku $70-80$ let a $20,1 \%$ ve věku nad 80 let a $14,1 \%$ ve věku 60-70 let.

Dále byla zjištována výška a hmotnost pacientů, $\mathrm{z}$ nichž se následně vypočetla hodnota Body Mass Index (BMI). Bylo zjištěno, že více než tři čtvrtiny respondentů trpí, nadváhou nebo obezitou. Nadváha se častěji vyskytovala u mužů, obezita u žen. Průměrná hodnota BMI u mužů je 28,87 a u žen 32,52 . Tento rozdíl je statisticky významný ( $\mathrm{p}=0,03827$ ).

Poměr pas/boky, neboli ukazatel WHR (Waist Hip Ratio) bylo možné spočítat pouze u 38 osob a to $\mathrm{z}$ důvodu chybějícího údaje u jedné osoby. Průměrné WHR bylo v souboru osob užívající warfarin $0,96 \mathrm{a}$ u osob užívajících nová antikoagulancia 0,95 . Mezi soubory nebyl zjištěn statisticky významný rozdíl ( $\mathrm{p}=0,7973$ ). U 77 \% mužů je hodnota WHR vyšší než 0,95 , tedy

Obrázek 1 Struktura dotazníku

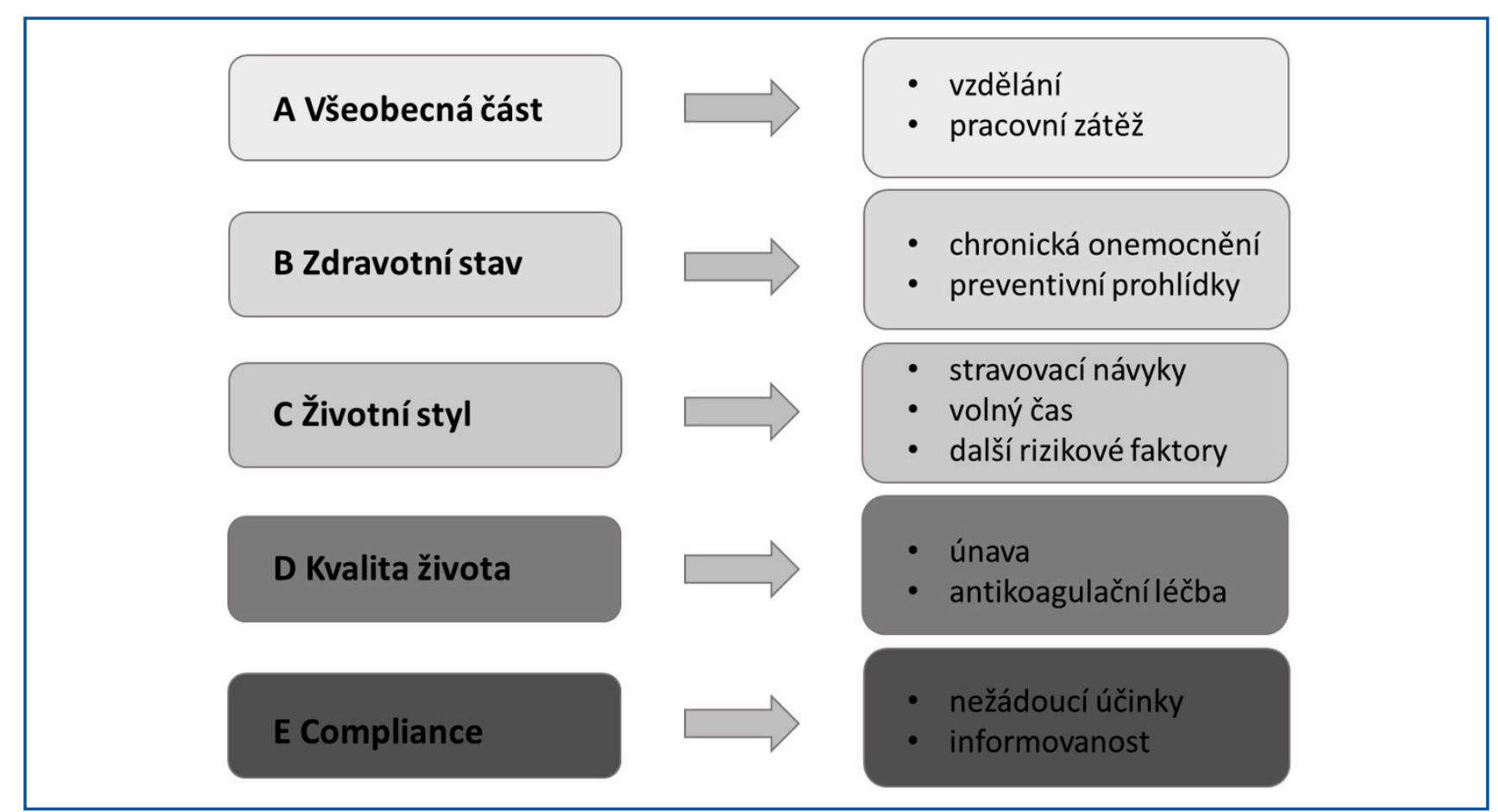


mají rizikový typ postavy. U žen má rizikový typ postavy, tedy hodnotu vyšší než $0,85,68$ \% žen. Průměrnou hodnotu indexu WHR měli muži 1,00 a ženy 0,95 . Tento rozdíl byl statisticky významný $(\mathrm{p}<0,001)$.

Průměrný systolický tlak $\mathrm{v}$ celém souboru byl 133,66 mmHg (SD 20,43; min. 96; max. 176). Průměrný diastolický krevní tlak byl $\mathrm{v}$ celém souboru 79,82 mmHg (SD 8,93; min. 57; max. 96). Průměrný tep v souboru je 70,66 tepů/min (SD 12,9; min. 40; max. 100).

Dále byly zjištovány komorbidity. Pouze jeden pacient neměl žádnou komorbiditu. Většina pacientů $(66,7 \%)$ mělo dvě a více komorbidit, 30,8 \% pacientů mělo jednu komorbiditu. Nejčastější udávanou komorbiditou byla u $82 \%$ pacientů hypertenze. Poté následoval u $28 \%$ pacientů diabetes mellitus II. typu.

Důvodem pro antikoagulační léčbu byla diagnóza fibrilace síně. Nejčastěji užívaným antikoagulanciem je warfarin a to u obou pohlaví. Ze souboru mužů užívá warfarin 69,57 \% osob a ze souboru žen $50 \%$. Druhým nejčastěji užívaným antikoagulanciem u mužů je Pradaxa a Eliquis (shodně 13,04 \%) a u žen Pradaxa (43,75\%). Rozdíl v užívání jednotlivých antikoagulancií mezi muži a ženami však není statisticky významný $(\mathrm{p}=0,2171)$. Průměrná délka uživání antikoagulancií je v celém souboru 39,59 měsíců. Rozdíl mezi pohlavími je téměř nulový. Muži užívají antikoagulancia v průměru 39,55 měsíců a ženy 39,64 měsíců. Délku užívání antikoagulancií neuvedlo 5 osob.

Nežádoucí účinky léčby uvedly 3 osoby (8\%), a to nadměrnou pigmentaci, hematomy a pocit krve $\mathrm{v}$ ústech. Všechny tři osoby užívaly Warfarin.

Dále byla zjištována pravidelnost docházení na lékařské prohlídky. Celých $95 \%$ pacientů chodí na pravidelné preventivní prohlídky ke svému praktickému lékaři. Zubního lékaře navštěvuje $72 \%$ pacientů. Preventivní prohlídky u gynekologa absolvuje ani ne polovina dotázaných žen (44\%).

\section{Compliance}

Nadpoloviční většina (51\%) pacientů nikdy nezapomíná užít svou léčbu. Jen jeden pacient zapomíná užívat poměrně často. Při cestách mimo domov si nezapomíná většina pacientů brát svou medikaci $(81 \%)$. Opět jeden pacient zapomíná velmi často. Jedná se o stejného pacienta co velmi často zapomíná užívat léky a jako jediný je velmi obtěžován dodržováním režimu. Dodržování předepsaného režimu užívání léků obtěžuje $11 \%$ pacientů. Celkem $89 \%$ pacientů nemá $s$ dodržováním režimu problémy.

Obecně s užíváním medikace nemá nikdy obtíže $69 \%$ pacientů. Recept si nezapomíná vyzvednout $97 \%$ pacientů.
Hospitalizován v souvislosti s nežádoucími účinky nebyl ani jeden proband. U tří osob se vyskytly nežádoucí účinky natolik závažné, že kvůli nim lékař vysadil antikoagulační léčbu. Jednalo se o pacienty užívající DOAC a byli to stejní pacienti, kteří v jedné z předchozích otázek uvedli vysazení léků. Ve dvou př́padech se jednalo o potíže s krvácením a $\mathrm{v}$ jednom prípadě o zažívací potíže v podobě průjmu.

Nadpoloviční většina pacientů (57 \%) je kontaktována každých 6 měsícủ ošetřujícím kardiologem. Uživatelé Warfarinu bývají kontaktování častěji, než uživatelé DOAC. Mezi uživateli DOAC a Warfarinu nebyl statisticky významný rozdíl ( $\mathrm{p}=0,288$ ).

Ze souboru pouze jeden pacient údajně nebyl žádným způsobem informován o dodržování správného léčebného postupu. Zbytek pacientů byl informován nejčastěji ústně (66\%) a ústně i písemně (29\%). Jeden proband na tuto otázku neodpověděl. Rozdíl v informovanosti vzhledem $\mathrm{k}$ uživané antikoagulační léčbě nebyl statisticky významný ( $\mathrm{p}=0,567)$.

Edukaci považuje za dostatečnou $63 \%$ pacientů. $37 \%$ z nich ji považuje za spiśe dostatečnou. Jako nedostatečnou nehodnotil zádný pacient. Informace o dietních opatřeních dostali všichni respondenti užívající warfarin. Nejčastěji ústně i písemně (65 \%), 26\% pacientů pouze ústně a $9 \%$ pouze písemnou formou. Jedna osoba neodpověděla.

\section{Kvalita života}

Kvalita života byla měřena pomocí dotazníku SF 12 (zkrácená verze SF 36). Tento typ dotazníku má 12 položek, které jsou rozděleny do osmi oblastí zájmu. Ty byly následně vyhodnoceny podle pohlaví a užívaného léku. Hodnotí se na stupnici $0-100$, kdy 0 je nejhorší a 100 je nejlepší.

$\mathrm{V}$ tabulce 1 jsou zaznamenány průměrné hodnoty, směrodatná odchylka, minimum a maximum hodnoty u mužů a u žen. Celkovou kvalitu života hodnotili lépe muži (průměrná hodnota 59,69; SD 27,2). Ženy kvalitu života hodnotily průměrně 51,71 (SD 28,4). Rozdíl mezi pohlavími je statisticky nevýznamný $(\mathrm{p}=0,3852)$. Muži nejlépe posuzovali oblast omezení rolí z psychických důvodů, (průměrná hodnota 87 ). Nejhůře posuzovanou oblastí u mužů byla energie, kterou označili průměrnou hodnotou 40 . Ženy nejlépe označovali stejnou oblast jako muži, ale proti mužům jen průměrnou hodnotou 76,7 . Nejnižší průměrná hodnota $\mathrm{u}$ žen vyšla $\mathrm{v}$ oblasti celkového zdraví (průměrná hodnota 39,1).

Statisticky významný rozdíl mezi pohlavími byl $\mathrm{v}$ oblastech emoční zdraví $(\mathrm{p}<0,001)$. Muži zde uváděli průměrnou hodnotu 79,1 a ženy pouze 51,3 . Obdobně v oblasti energie ( $\mathrm{p}=4395)$, kterou naopak 
hodnotili muži hůře (průměr 40), než ženy (průměr 60 ). Ve zbylých oblastech byl rozdíl statisticky nevýznamný.

Celkově kromě oblasti energie vyhodnocovali muži svou kvalitu života lépe, než ženy. Celkovou kvalitu života vyhodnocovali obě skupiny téměř shodně. $\mathrm{V}$ případě osob, užívajících DOAC, to bylo $\mathrm{v}$ prüměru 56,25 (SD 29,24) a $\mathrm{v}$ př́padě osob, užívajících Warfarin, to bylo průměrně 56,37 (SD 28,53). Rozdíl mezi těmito skupinami nebyl statisticky významný $(\mathrm{p}=0,99)$.

\section{DISKUSE}

Důvodem k antikoagulační léčbě v souboru byla fibrilace síní. Ta patří mezi kardiovaskulární onemocnění, jehož incidence i prevalence stoupá a to nejen v České republice, ale i ve světě. Prevalence pak roste exponenciálně s věkem a postihuje až $10 \%$ populace starší 80 let. Uvádí se, že na celém světě je FS postiženo kolem 30 milionů pacientů. Mezi sledované neovlivnitelné rizikové faktory patří genetika, pohlaví a věk. Mezi další významné rizikové faktory patří například obezita, metabolický syndrom, onemocnění štítné žlázy a mnohá kardiovaskulární onemocnění jako je hypertenze a podobně. Při pohledu na vyjmenované rizikové faktory se nabízí prevence a to zejména $\mathrm{v}$ oblasti životního stylu. Jedná se zejména o cílené snižování nadváhy, zdravá, vyvážená a dostatečná (vhodná) pohybová aktivita (4).

$S$ ohledem na výše uvedené rizikové faktory byly zjištovány následující parametry. $\mathrm{V}$ souboru pacientů byla většina ve věku nad 60 let, a to konkrétně $64,4 \%$ ve věku $70-80$ let a $20,1 \%$ ve věku nad 80 let a $14,1 \%$ ve věku 60-70 let. Je zde tedy patrný trend zvyšující se incidence ve vyšších věkových skupinách populace. Dále byla $\mathrm{z}$ rizikových faktorů sledována hodnota po- měr pas/boky (WHR - $\mathrm{z}$ anglického waist hips ratio). U 77 \% mužů je hodnota WHR vyšší než 0,95 , tedy mají rizikový typ postavy. U žen má rizikový typ postavy, tedy hodnotu vyšší než 0,85, 68 \% žen. Rozdíl v pohlaví byl zřejmý, ale je to dáno odlišnou konstitucí těla. Lze ale rozhodně říci, že tento rizikový faktor byl př́tomný u nadpoloviční většiny pacientů. Průměrný systolický tlak v celém souboru byl 133,66 mmHg (SD 20,43; min. 96; max. 176), což je stále ve fyziologickém rozpětí, nicméně se pomalu bliží $\mathrm{k}$ hodnotám hypertenze. Poté následoval u $28 \%$ pacientů diabetes mellitus II. typu. V oblasti zjištovaných rizikových faktorů by bylo více než na místě edukovat pacienty o změně životního stylu. Je třeba apelovat na pacienty, aby si osvojili jednoduché životní návyky jako je pravidelný a přiměřený pohyb a zdravá vyvážená strava. Mnohé z rizikových faktorů jsou faktory životního stylu a co je hlavní, mnohé $\mathrm{z}$ nich jsou efektivně preventabilní. Pro zdraví každého pacienta by bylo jistě velmi pozitivní celkové zlepšení zdravotního stavu v důsledku udržování fyzické kondice, zdravého jídelníčku, udržování optimální váhy a tím i výrazným zkvalitněním zdraví a jeho vlastní vnímání jedincem.

Co se týče antikoagulační léčby, všichni pacienti užívali antikoagulancia z důvodu fibrilace síní. Nejčastěji užívaným antikoagulanciem byl Warfarin (61 \%). Ze souboru mužů užívá warfarin $69,57 \%$ a ze souboru žen $50 \%$. Druhým nejčastěji užívaným antikoagulanciem u mužů je Pradaxa a Eliquis (shodně u obou $13,04 \%$ ) a u žen byla užívaná Pradaxa ve $43,75 \%$. Warfarin je nadále nejčastěji užívané antikoagulancium, což reflektují počty v souboru.

\section{Kvalita života}

Celkovou kvalitu života hodnotili lépe muži (průměrná hodnota 59,69; SD 27,2). Ženy kvalitu života

Tabulka 1 Srovnání hodnocení kvality života v jednotlivých oblastech podle pohlaví

\begin{tabular}{|c|c|c|c|c|c|c|c|c|}
\hline \multirow{2}{*}{ Oblasti } & \multicolumn{4}{|c|}{ Muži } & \multicolumn{4}{|c|}{ Ženy } \\
\hline & Průměr & $S D$ & Min & Max & Průměr & $S D$ & Min & Max \\
\hline SF & 64,8 & 30,2 & 0 & 100 & 49,3 & 25,2 & 0 & 80 \\
\hline B & 51,1 & 30,6 & 0 & 100 & 43,8 & 22,5 & 25 & 100 \\
\hline$F Z$ & 52,2 & 32,7 & 0 & 100 & 41,9 & 36,1 & 0 & 80 \\
\hline$C Z$ & 42,4 & 11,5 & 25 & 50 & 39,1 & 21,6 & 0 & 75 \\
\hline EZ & 79,1 & 15,7 & 60 & 100 & 51,3 & 26,3 & 0 & 100 \\
\hline FD & 60,9 & 37,5 & 0 & 100 & 51,6 & 35,8 & 0 & 100 \\
\hline PD & 87 & 33,7 & 0 & 100 & 76,7 & 42,1 & 0 & 100 \\
\hline $\mathbf{E}$ & 40 & 25,6 & 0 & 100 & 60 & 17,9 & 40 & 100 \\
\hline
\end{tabular}

Vysvětlivky: SF- sociální funkce; B- bolest; FZ- fyzické zdraví; CZ- celkové zdraví; EZ- emoční zdraví; FD- omezení rolí z fyzických důvodů; $\mathrm{PD}$ - omezení rolí z psychických důvodů; E- energie; SD- směrodatná odchylka 
hodnotily průměrně 51,71 (SD 28,4). Rozdíl mezi pohlavími je statisticky nevýznamný ( $\mathrm{p}=0,3852)$. V př́ipadě osob, užívajících DOAC, to bylo v průměru 56,25 (SD 29,24) a v př́padě osob, užívajících Warfarin, to bylo průměrně 56,37 (SD 28,53). Rozdíl mezi těmito skupinami nebyl statisticky významný $(\mathrm{p}=0,99)$. Pro přesnější statistické vyhodnocení by bylo vhodnější doplnit soubor o další pacienty. Někdy není jednoduché zhodnotit sledované parametry $\mathrm{z}$ důvodu velkého množství dotazníků, které nejsou zcela sjednocené. Každopádně i studie s několika stovkami pacientů nevykazují výraznější rozdíly v kvalitě života a adherenci u pacientů s DOAC oproti Warfarinu, jak uvádí uvedená francouzská observační studie. Ta ukázala, že pacienti s fibrilací síní uvádějí větší spokojenost $s$ ambulantní léčbou př́mými antikoagulancii, než s antagonisty vitaminu $\mathrm{K}$. Kvalita života a adherence $\mathrm{k}$ léčbě se u obou skupin léků významně neliší. Jednalo se o observační deskriptivní epidemiologickou studii. Hodnocena byla kvalita života pacientů pomocí dotazníku EQ-5D (EuroQol 5-Dimensions), spokojenost s léčbou pomocí dotazníku PACT-Q2 (Perception of AntiCoagulant Treatment Questionnaire 2) a adherence k léčbě pomocí dotazníku MMAS-8 (8-item Morisky Medication Adherence Scale). Zařazeno bylo 200 pacientů s fibrilací síní, kteří ambulantně užívali antikoagulační léčbu nejméně 3 měsíce. Analyzovány byly skupiny pacientů s primární léčbou VKA $(\mathrm{n}=89)$, s DOAC po předchozí léčbě VKA $(\mathrm{n}=50)$ a s primární léčbou DOAC $(n=52)$. Kvalita života i spokojenost s léčbou byly ve všech skupinách dobré. Kvalita života a adherence $k$ léčbě se mezi jednotlivými skupinami nelišily. Spojenost s léčbou ovšem byla významně větší u obou skupin s DOAC v porovnání se skupinou s VKA v dimenzích „pohodlí a "spokojenost“" $(p<0,001)(3)$.

$\mathrm{V}$ litevské studii se pak snažili určit a zjistit, zda existuje statisticky významný rozdíl při srovnání kvality života $\mathrm{v}$ souvislosti se zdravím osob užívajících antagonisty vitaminu $\mathrm{K}$, warfarin a nová perorální antikoagulancia (novel oral anticoagulant, NOAC) rivaroxaban a dabigatran ve srovnání s pacienty neužívajícími žádné perorální antikoagulancium.Výzkumný projekt s použitím prưřezové analýzy byl proveden na Klinice kardiologie Fakultní nemocnice Pauls Stradins v litevské Rize v období od října 2016 do června 2017. Účast $\mathrm{v}$ tomto výzkumném projektu byla nabídnuta osobám s vysokým rizikem nevalvulární fibrilace síní. $\mathrm{V}$ př́padě souhlasu s účastí byl s pacientem proveden ústní pohovor s dotazy na osobní anamnézu, demografické údaje, výsledky laboratorních testů i výsledky echokardiografického vyšetření, výsledky modifikovaného dotazníku SF-36 a užívaný typ NOAC. Údaje byly ověřeny na základě informací osobní anamnézy účastníka výzkumu. Do výzkumu bylo zařazeno celkem 218 pacientů $(56,9$ \% žen a $43,1 \%$ mužů průměrného věku 70,4 roku $\mathrm{s}$ průměrnou hodnotu skóre CHA2D2-VASc 4,4. Warfarin užívalo 37,6 \% pacientů, NOAC 33,0 \%, žádná perorální antikoagulancia neužívalo 29,4 \% účastníků výzkumu. Statisticky významný rozdíl byl zjištěn mezi průměrnými hodnotami dimenzí fyzického fungování při srovnání osob užívajících warfarin (průměr 95,85) nebo NOAC (průměr 124,57); $\mathrm{p}=0,012$. Statisticky významný rozdíl byl rovněž prokázán $\mathrm{v}$ dimenzi sociálního fungování při srovnání účastníků výzkumu užívajících warfarin (průměr 96,16) nebo NOAC (průměr 119,08); $\mathrm{p}=0,026$. Negativní korelace mezi věkem a fyzickým fungováním dosáhla nízké hodnoty $(\mathrm{r}=-0,23)$. Důležitým zjištěním bylo, že užívání NOAC koreluje $\mathrm{s}$ nejvyššími hodnotami skóre kvality života $\mathrm{v}$ souvislosti se zdravím; byl nalezen statisticky významný rozdíl oproti osobám užívajícím warfarin v dimenzi fyzického fungování (warfarin 95,85; NOAC 124,57; $\mathrm{p}=0,012$ ) i sociálního fungování (warfarin 95,16; NOAC 119,08; $p=0,026)$. Negativní korelace se skóre fyzického fungování dosáhla nízkých hodnot. Možnost dalšího rozšíření studie nových antikoagulancií je právě srovnání kvality života osob bez léčby a osob s DOAC a Warfarinem (5).

\section{COMPLIANCE}

Důležitost compliance spočívá $\mathrm{v}$ tom, že pacienti mohou být $\mathrm{v}$ důsledku zjištěné nízké compliance (špatně zvolené dávky, výskytu lékových interakcí nebo zhoršení renálních funkcí) ohroženi jak selháním léčby, tak krvácením, které může být život ohrožující. Rivaroxaban je $\mathrm{z}$ hlediska compliance vhodné podávat jedenkrát denně, což bylo ve studii dodrženo (6).

Potřeba př́sného monitorování INR u warfarinu může být považována za nevýhodu, avšak dává lékaři možnost kontrolovat complianci pacienta. Toto u DOACs není možné (nebo je problematické). Sekundární analýza studie RE-LY ukázala, že přednosti dabigatranu u všech cévních př́hod a mortality byly větší v centrech se špatnou kontrolou INR než $\mathrm{v}$ centrech s dobře kontrolovaným INR, což ukazuje, že výhody DOACs mohou záviset také na lokálních standardech péče $(7,8,9)$.

U compliance nebyl zjištěn $u$ všech zjištovaných složek statisticky významný rozdíl u pacientů s DOAC oproti pacientům užívají warfarin. U nikoho z pacientů se nevyskytoval častý problém s užitím antikoagulační terapie. Obdobně byly obě skupiny pacientů informovány o správném postupu léčby. Skupina pacientů užívající Warfarin byla vhodně poučena o dietních omezení. Informace pak hodnotili jako dostatečné, či 
spíše dostatečné. V souboru byla pouze jedna osoba, která nedostala informace ohledně antikoagulační léčby. Majoritní většina pacientů je pravidelně zvána na kontrolní a preventivní prohlídky. Informovanost o konkrétním léčebném postupu zahrnující i informace $\mathrm{k}$ antikoagulační léčbě má velký vliv na léčbu samotnou. $\mathrm{Z}$ důvodu nízkého počtu pacientů nebyla možnost zjistit více negativních odpovědí $\mathrm{v}$ této sledované oblasti.

Základním předpokladem studie byl fakt, že užívání DOAC má jednoduší schéma, není tř̌eba dietního omezení a časté monitorace oproti pacientům uživají Warfarin. Tento předpoklad se snažila vyhodnotit i studie (Arizona), kde byly zjištovány pomocí dotazníku MMAS-8 hodnoty compliance. Rozdíl byl zjištěn jako statisticky nevýznamný $(\mathrm{p}=8)$, což potvrzuje i naše studie. Je ale třeba zdưraznit nízký počet respondentů (10).

Nová perorální antikoagulancia mají dobře predikovatelný účinek. Jak již bylo uvedeno, není nutná monitorace antikoagulačního účinku pro vedení léčby mimo neobvyklé klinické situace (jako jsou interkurentní onemocnění). Antikoagulační účinek však rychle klesá 12-24 hodin po poslední dávce. Proto je zcela zásadní velmi dobrá compliance pacienta. I kdyby se používaly vhodné nové antikoagulační testy s cílem hodnotit koncentrace $\mathrm{v}$ plazmě, nebyly by použitelné jako pomůcka $\mathrm{k}$ monitoraci compliance pacienta, protože jejich interpretace je velmi závislá na načasování testu vzhledem $\mathrm{k}$ poslední dávce léku, a nevypovídají nic o compliance před onou poslední dávkou. Lékaři proto potřebují najít způsob, jak optimalizovat compliance pacientů, která se pro většinu léků v denní praxi pohybuje $\leq 80 \%$.

Dalším, již výše nastíněným, problémem je použití mnohých, často nestandardizovaných testů. $V$ př́padě validovaných dotazníků se pro měření adherence se využívá např. MMAS (Morisky Medication Adherence Scale), a to ve formě $4(11,12)$ nebo 8 otázek $(13)$. Tento typ dotazníku byl původně validován pro antihypertenzní terapii $(12,14)$, v dnešní době se používá i jako standard při validaci jiných dotazníků. První 4, resp. 7 otázek je postaveno na odpovědi ano/ne, 8. otázka je založena na pětistupňové Likertově škále. Ve většině studií byla na základě tohot testu pozorována byla spíše nižší míra adherence $\mathrm{k}$ léčbě dabigatranem a spíše vyšší u léčby rivaroxabanem. $Z$ důvodu nízkého počtu pacientů tento trend nebyl potvrzen $(12,13,15,16,17,18,19,20)$.

Ve srovnání DOAC a VKA (vitamin $\mathrm{K}$ antagonist - antagonisté vitaminu $K$ ) se vyšší adherencí (pojem velmi úzce souvisí s compliance) i spokojeností s léčbou většinou projevovali pacienti uží- vající $\mathrm{DOAC}$, případně byly rozdíly poměrně malé. U apixabanu ve srovnání s ostatními antikoagulancii byly výsledky naprríč studiemi relativně nekonzistentní. Téměř všechny studie, které monitorovaly adherenci v průběhu delšího časového období, se však shodovaly $\mathrm{v}$ postupném poklesu adherence $\mathrm{k}$ léčbě $s$ časem (12).

$Z$ výsledků studií je často evidentní, že se výzkum $\mathrm{v}$ této problematice slibně rozvijí, i když jsou zde stále určité rezervy. Porovnání studií bylo poměrně obtížné $\mathrm{z}$ důvodu jejich velké variability v mnoha okolnostech. Př́kladem je různorodost zastoupení hodnocených antikoagulancií, největší počet studií hodnotil samostatně dabigatran a nejméně bylo studií týkajících se apixabanu či edoxabanu. Tyto rozdíly byly patrně mimo jiné dány nestejnou dobou setrvání jednotlivých zástupců na trhu $(12,15)$.

Zásadní vliv na výslednou míru adherence $\mathrm{k}$ léčbě může mít i metoda získávání dat. Prozatím není $\mathrm{k}$ dispozici jednoduchý, dostatečně objektivní a spolehlivý způsob použitelný pro měření adherence $\mathrm{k}$ DOAC (22). Dotazníkové šetření může být ovlivněno subjektivním pohledem pacienta, a tak může docházet $\mathrm{k}$ nadhodnocení míry adherence $\mathrm{k}$ léčbě $(11,22,24$, $25,26)$. Nejvýhodnější je zřejmě kombinace více metod měření adherence, které mohou zohlednit více faktorů nonadherence $\mathrm{k}$ léčbě $(12,27,28)$.

Kardiovaskulární onemocnění a jejich léčba byla v mnoha publikacích považována za faktor podporující adherenci, pravděpodobně $z$ důvodu častějšího kontaktu se zdravotníkem a porozumění důležitosti léčby $(12,26,29)$, př́ípadně díky vzniku určitého návyku pravidelně užívat léčiva $(12,26)$. Předchozí zkušenost s CMP (cévní mozková př́íhoda) nebo TIA (tranzitorní ischemická ataka) byla také vnímána jako okolnost zvyšující adherenci $(12,13)$, protože se jedná o poměrně dramatickou událost $\mathrm{v}$ životě postižených pacientů $(12,16)$. Značný vliv na zlepšení adherence měl i dostatečný kontakt pacienta se zdravotníkem a edukace pacientů $(12,30,31,32)$, dále také monitoring minoritních nežádoucích účinků, které by mohly vést $\mathrm{k}$ samovolnému přerušení léčby, i když jim lze vhodnými opatřeními předcházet. Souhrnně lze uvést, že individuální přístup $\mathrm{k}$ pacientovi a další aktivity $\mathrm{v}$ managementu adherence $\mathrm{k}$ léčbě ve zdravotnických zařízeních mohou podporovat adherenci $\mathrm{k}$ léčbě (33).

Výsledky studií se nejčastěji z hlediska vyšší adherence $\mathrm{k}$ léčbě přiklánějí $\mathrm{k}$ užívání rivaroxabanu, a naopak spíše nižší míra adherence je popisována u dabigatranu. Výsledky studií zabývající se touto tématikou ale nejsou jednoznačně uniformní a mají určité limitace, nicméně lze očekávat, že budou potvrzeny v na- 
vazujícím výzkumu, který se $\mathrm{v}$ současné době značně rozvíjí (12).

\section{LIMITY}

Limity studie jsou dány zejména nepř́íznivou epidemiologickou situací, která se odrazila zejména v nízkém počtu pacientů, kteří se výzkumu zúčastnili. Další nevýhodou byl poměrně rozsáhlý dotazník a současně nízká ochota pacientů vyplnit dotazník v ambulanci.

\section{ZÁVĚRY}

Nová př́má perorální antikoagulancia vykazují vysoký potenciál zejména co se týče způsobu uživání. $\mathrm{V}$ tomto smyslu se zdá, že pacientům přináší DOAC oproti Warfarinu mnohé výhody a to nejen výhodný bezpečnostní profil, jednoduchost užívání ale i odpadnutí nutnosti časté monitorace během léčby. $\mathrm{Na}$ trhu jsou ale teprve několik let a je třeba zjištovat potřeby pacientů. Také je na místě edukace pacienta o léčbě jako takové a současně o vhodnosti dodržováním preventivních opatření ve smyslu snížení výskytu komorbidit a rizikových faktorů, které snižují kvalitu života, zatěžují pacienta a mohou snižovat i compliance pacienta. Optimální pravidelný pohyb a zdravá vyvážená strava by pak měla být součástí životního stylu každého pacienta.

\section{REFERENČNÍ SEZNAM}

1. Čihák R et al., Updated European Heart Rhythm Association Practical Guide on the use of non-vitamin $\mathrm{K}$ antagonist anticoagulants in patients with non-valvular atrial fibrillation: Summary of the document prepared by the Czech Society of Cardiology, Cor et Vasa 58 (2016) e153-e174, jak vyšel v online verzi Cor et Vasa na http:// www.sciencedirect.com/science/article/pii/ S0010865016000084

2. Apsite A, et al., Atrial fibrillation, oral anticoagulants and health related quality of life? Cor et Vasa 60 (2018) e597-e602 as published in the online version of Cor et Vasa available at https:// www.sciencedirect.com/science/article/pii/ S0010865017301558

3. Benzimra M., Bonnamour B., Duracinsky M. et al. Real-life experience of quality of life, treatment satisfaction, and adherence in patients receiving oral anticoagulants for atrial fibrillation. Patient Prefer Adherence 2018 Jan 4; 12: 79-87, doi: 10.2147/PPA.S131158.

4. Zatloukalová A. Epidemiology of atrial fibrillation. Profese online [online]. 2020, 13(1), 56-64 [cit. 2020-10-05]. ISSN 18034330. Dostupné z: doi: $10.5507 /$ pol.2020.008
5. Apsite K, Lurina B, Tupahins A, Voicehovskis V, Ivascenko T, Kalejs $\mathrm{O}$ a Lejnieks A. Atrial fibrillation, oral anticoagulants and health related quality of life. Cor et Vasa. 2018, 60(6), e597-e602. ISSN 00108650. Dostupné z: doi:10.1016/j. crvasa.2017.12.012

6. De Vriese AS, Caluwé R, Bailleul E, et al. Dosefinding study of rivaroxaban in hemodialysis patients. Am J Kidney Dis 2015;66:91-98.

7. Granger CHB, Alexander JH, McMurray JJV, et al. Apixaban versus Warfarin in Patients with Atrial Fibrillation. New England Journal of Medicine. 2011, 365(11), 981-992. ISSN 0028-4793. Dostupné z: doi:10.1056/NEJMoa1107039

8. Wallentin L, Yusuf S, Ezekowitz MD et al. Effi cacy and safety of dabigatran compared with war farin at diff erent levels of international normalized ratio control for stroke preven-tion in atrial fi brillation: An analysis of the RE-LY trial. Lancet. 2010, Sv. 376, 975-983

9. Čihák R, et al., European Heart Rhythm Association practical guide on the use of new oral anticoagulants in patients with non-valvular atrial fibrillation. Summary of the document prepared by the Czech Society of Cardiology, Cor et Vasa 56 (2014) e42-e56, jak vyšel v online verzi Cor et Vasa na http://www.sciencedirect.com/science/ article/pii/S001086501300129X

10. Patel SI, Cherington CH, Scherber R, et al. Assessment of Patient Adherence to Direct Oral Anticoagulant vs Warfarin Therapy. The Journal of the American Osteopathic Association [online]. 2017, 117(1) [cit. 2020-04-23]. DOI:10.7556/ jaoa.2017.002. ISSN 0098-6151. Dostupné z: http:// jaoa.org/article.aspx?doi=10.7556/jaoa.2017.002

11. Castellucci LA, Shaw J, Van Der Salm K et al. Self-reported adherence to anticoagulation and its determinants using the Morisky medication adherence scale. Thromb Res 2015; 136(4): 727-731. Dostupné z DOI: <http://dx.doi.org/10.1016/j. thromres.2015.07.007>.

12. Obamiro KO, Chalmers L, Bereznicki LRE, Voicehovskis V, Ivascenko T, Kalejs O a Lejnieks A. A Summary of the Literature Evaluating Adherence and Persistence with Oral Anticoagulants in Atrial Fibrillation. American Journal of Cardiovascular Drugs. 2016, 16(5), 349-363. ISSN 1175-3277. Dostupné z: doi:10.1007/ s40256-016-0171-6

13. Luger S, Hohmann C, Niemann D, et al. Adherence to oral anticoagulant therapy in secondary stroke prevention - impact of the novel oral anticoagulants. Patient Prefer Adherence 2015; 9: 
1695-1705. Dostupné z DOI: http://dx.doi. org/10.2147/PPA.S88994

14. Morisky DE, Green LW, Levine DM. Concurrent and predictive validity of a self-reported measure of medication adherence. Med Care 1986; 24(1): 67-74.

15. Andrade JG, Krahn AD, Skanes AC et al. Values and Preferences of Physicians and Patients With Nonvalvular Atrial Fibrillation Who Receive Oral Anticoagulation Therapy for Stroke Prevention. Can J Cardiol 2016; 32(6): 747-753. Dostupné z DOI: <http://dx.doi.org/10.1016/j. cjca.2015.09.023>.

16. Beyer-Westendorf J, Ehlken B, Evers T. Real-world persistence and adherence to oral anticoagulation for stroke risk reduction in patients with atrial fibrillation. Europace 2016; 18(8): 1150-1557. Dostupné z DOI: http://dx.doi.org/10.1093/europace/ euv421

17. Forslund T, Wettermark B, Hjemdahl P. Comparison of treatment persistence with different oral anticoagulants in patients with atrial fibrillation. Eur J Clin. Pharmacol 2016; 72(3): 329-338. Dostupné z DOI: http://dx.doi.org/10.1007/ s00228-015-1983-z

18. Alberts MJ, Peacock WF, Fields LE et al. Association between once- and twice-daily direct oral anticoagulant adherence in nonvalvular atrial fibrillation patients and rates of ischemic stroke. Int J Cardiol 2016; 215: 11-13. Dostupné z DOI: http://dx.doi.org/10.1016/j.ijcard.2016.03.212

19. Brown JD, Shewale AR, Talbert JC. Adherence to Rivaroxaban, Dabigatran, and Apixaban for Stroke Prevention in Incident, Treatment-Naïve Nonvalvular Atrial Fibrillation. J Manag Care Spec Pharm 2016; 22(11): 1319-1329.

20. Yao X, Abraham NS, Alexander GC et al. Effect of Adherence to Oral Anticoagulants on Risk of Stroke and Major Bleeding Among Patients With Atrial Fibrillation. J Am Heart Assoc 2016; 5(2). pii: e003074. Dostupné z DOI: http://dx.doi. org/10.1161/JAHA.115.003074

21. Andrade JG, Krahn AD, Skanes AC et al. Values and Preferences of Physicians and Patients With Nonvalvular Atrial Fibrillation Who Receive Oral Anticoagulation Therapy for Stroke Prevention. Can J Cardiol 2016; 32(6): 747-753. Dostupné z DOI: http://dx.doi.org/10.1016/j. cjca.2015.09.023

22. Hu YF, Liao JN, Chern CM et al. Identification and management of noncompliance in atrial fibrillation patients receiving dabigatran: the role of a drug monitor. Pacing Clin Electrophysiol 2015;
38(4): 465-471. Dostupné z DOI: http://dx.doi. org/10.1111/pace. 12575

23. Castellucci LA, Shaw J, Van Der Salm K et al. Self-reported adherence to anticoagulation and its determinants using the Morisky medication adherence scale. Thromb Res 2015; 136(4): 727-731. Dostupné z DOI: http://dx.doi. org/10.1016/j.thromres.2015.07.007

24. Michel J, Mundell D, Boga T et al. Dabigatran for anticoagulation in atrial fibrillation - early clinical experience in a hospital population and comparison to trial data. Heart Lung Circ 2013; 22(1): 50-55. Dostupné z DOI: http://dx.doi. org/10.1016/j.hlc.2012.09.002

25. Hanon O, Chaussade E, Gueranger P et al. Patient-Reported Treatment Satisfaction with Rivaroxaban for Stroke Prevention in Atrial Fibrillation. A French Observational Study, the SAFARI Study. PLoS One 2016; 11(12): e0166218. Dostupné z DOI: http://dx.doi.org/10.1371/journal. pone. 0166218

26. Polymeris AA, Traenka C, Hert L et al. Frequency and Determinants of Adherence to Oral Anticoagulants in Stroke Patients with Atrial Fibrillation in Clinical Practice. Eur Neurol 2016; 76(3-4): 187-193.

27. Vrijens B, Heidbuchel $H$. Non-vitamin $K$ antagonist oral anticoagulants: considerations on once- vs twice-daily regimens and their potential impact on medication adherence. Europace 2015; 17(4): 514-523. Dostupné z DOI: http://dx.doi. org/10.1093/europace/euu311

28. Lee PY, Han SY, Miyahara RK. Adherence and outcomes of patients treated with dabigatran: pharmacist-managed anticoagulation clinic versus usual care. Am J Health Syst Pharm 2013; 70(13): 1154-1161. Dostupné z DOI: http://dx. doi.org/10.2146/ajhp120634

29. Gorst-Rasmussen A, Skjoth F, Larsen TB et al. Dabigatran adherence in atrial fibrillation patients during the first year after diagnosis: a nationwide cohort study. J Thromb Haemost 2015; 13(4): 495-504. Dostupné z DOI: http://dx.doi. org/10.1111/jth. 12845

30. Schulman S, Shortt B, Robinson $M$ et al. Adherence to anticoagulant treatment with dabigatran in a real-world setting. J Thromb Haemost 2013; 11(7): 1295-1299. Dostupné z DOI: http://dx.doi. org/10.1111/jth.12241

31. SPC Pradaxa. Dostupné z WWW: http://www. ema.europa.eu/docs/cs_CZ/document_library/ EPAR_-_Product_Information/human/000829/ WC500041059.pdf 
32. Kilickiran Avci B, Vatan B, Ozden Tok O et al. The Trends in Utilizing Nonvitamin K Antagonist Oral Anticoagulants in Patients With Nonvalvular Atrial Fibrillation: A Real-Life Experience. Clin Appl Thromb Hemost 2016; 22(8): 785-791.

33. Shore S, Ho PM, Lambert-Kerzner A et al. Sitelevel variation in and practices associated with dabigatran adherence. JAMA 2015; 313(14): 1443-1450. Dostupné z DOI: http://dx.doi. org/10.1001/jama.2015.2761

\section{KORESPONDUJÍCÍ) AUTOR}

Mgr. Anna Zatloukalová, Ph.D.

Univerzita Palackého Olomouc

Fakulta zdravotnických věd

Ústav zdravotnického managementu

Hněvotínská 976, Nová Ulice, 77515 Olomouc

anna.zatloukalova@upol.cz

tel. 585632861

Publikace vznikla za podpory grantu s registračním číslem SGS10/LF/2019: „Životní styl, kvalita života a compliance pacientů užívajících antikoagulancia-pilotní studie“ v rámci Studentské grantové soutěže Ostravské univerzity.

Děkuji studentkám LF OU Bc. Veronice Kuželové a Bc. Michaele Zárubové za pomoc s realizací pilotní studie. 